Available online at http://www.anpad.org.br/bar

BAR, Rio de Janeiro, v. 10, n. 4, art. 4, pp. 439-461, Oct./Dec. 2013 Review

\title{
The Impact of Credit Rating Changes in Latin American Stock Markets
}

Abner de Pinho Nogueira Freitas E-mail address: abnerfreitas@gmail.com

Insper Instituto de Ensino e Pesquisa Av. Higienopolis, 15, apto. 173P, 01238-001, São Paulo, SP, Brazil.

Andrea Maria Accioly Fonseca Minardi E-mail address: minardi@insper.edu.br Insper Instituto de Ensino e Pesquisa Rua Quata, 300, Vila Olimpia, 04546-042, São Paulo, SP, Brazil.

Received 10 June 2012; received in revised form 8 April 2013; accepted 26 June 2013; published online $1^{\text {st }}$ October 2013.

Editor's note. Ricardo Pereira Câmara Leal served as Associate Editor for this article. 


\begin{abstract}
Our objective is to examine whether a rating change or Credit Watch announcement has a significant impact on Latin American stock prices. We conducted an event study to analyze stock market reaction to such news in the four major Latin American economies: Argentina, Brazil, Chile and Mexico. We find similar results to those previously observed in the literature, wherein the impact is quite significant for rating downgrades but less relevant for rating upgrades and Credit Watches. We also run cross section regressions to investigate which variables best explain the impact rating changes announcements have on stock prices in these countries. The results indicate that the most significant variable is the absolute change in the number of notches for downgrades. We conclude that credit ratings are relevant information in Latin America.
\end{abstract}

Key words: rating change announcement; Credit Watch; event study. 


\section{Introduction}

Several investors and financial institutions rely on credit ratings because they summarize the creditworthiness of an issuer or issue in a single grade. The main rating agencies are Moody's, Fitch and Standard \& Poor's (S\&P).

The agencies issue a credit opinion based on analysis of financial and qualitative aspects of the issuer or issue. This grade reflects a default probability. AAA to BBB- for S\&P and Fitch and Aaa to Baa3 for Moody's, ordered from best to worst credit quality, are considered investment grades and reflect a very low or almost nonexistent default probability. BB+ to CC for S\&P and Fitch and Ba1 to $\mathrm{Ca} 1$ for Moody's are considered speculative grades and reflect a higher default probability. There are also grades for selective default (SD) and default (D).

The agencies disclose rating changes (upgrades and downgrades) of an issuer or issue. They also announce Credit Watch (S\&P), Rating Watch (Fitch) or Watch List (Moody's). According to Standard and Poor's (2009), a Credit Watch means that a rating has been placed under review until further data about the event causing the change in credit perception have been obtained, without necessarily changing the rating after obtaining the missing information. S\&P uses Credit Watch when it believes that a credit opinion is likely to be issued within 90 days.

Agencies apply through-the-cycle methodology in rating assignments, and many times they are criticized for delaying rating downgrades or upgrades in relation to financial markets. But according to Altman and Rijken (2006), investors and regulators desire some level of stability, and do not want rating changes to reflect small changes in financial conditions. Therefore agencies filter out temporary credit risk components. This way rating changes reflect only long-term structural components, and agencies avoid excessive rating reversals, bearing the cost of some delay in relation to the financial market pricing of securities. Altman and Rijken (2006) also point out that agencies monitor the permanent credit risk component for substantial changes. A rating change, on average, only partially adjusts to the perceived level of a long-term credit risk component. The authors called this policy prudent migration, but emphasized that it is not officially disclosed by the agencies.

Regarding rating and capital market development in Latin American, Figure 1 and Figure 2 reflect the evolution of investors' interests in the region. Figure 1 shows a significant increase in market capitalization since 2004 in the four countries we analyze.

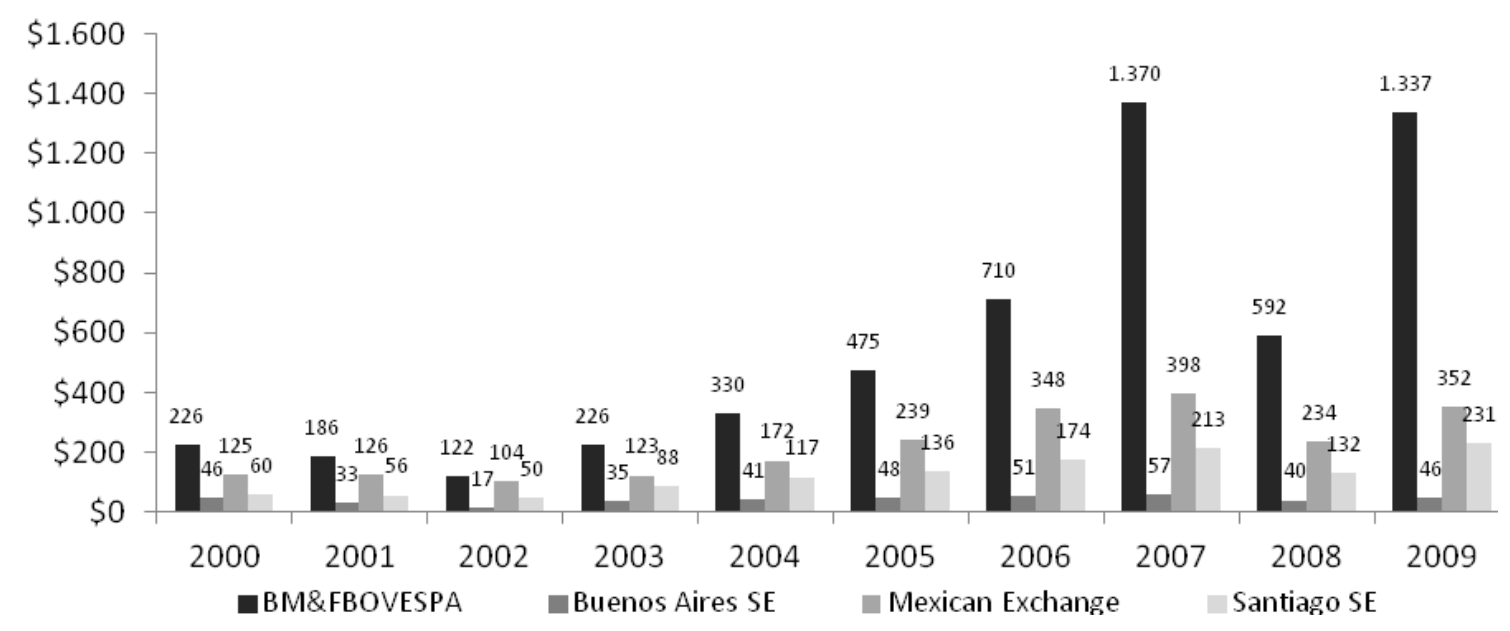

Figure 1. Evolution of Market Capitalization in the Main Latin American Markets in USD (\$ Billions). 
Source: World Federation of Exchanges. (2010). Domestic market capitalization (in USD millions). Retrieved from http://www.world-exchanges.org/files/statistics/excel/Ts2\%20Market\%20cap..XLS

Rating agencies' coverage of Latin America has also increased significantly since 2004, as we can observe in Figure 2. Latin American companies' credit quality has improved considerably. In July 2010, 40\% of Moody's ratings in Latin America consisted of investment-grade companies, whereas in December 1999, this percentage was only 19\% (Moody's, 2010).

Despite rating agencies' growing interest in Latin America, the region still displays significant vulnerabilities. For example, Argentina went into default in 2001 and still has a limited bond-issuing market in terms of volume and duration when compared to the Chilean market. Argentina is the only country analyzed in this study to receive a speculative grade at the time of this research.

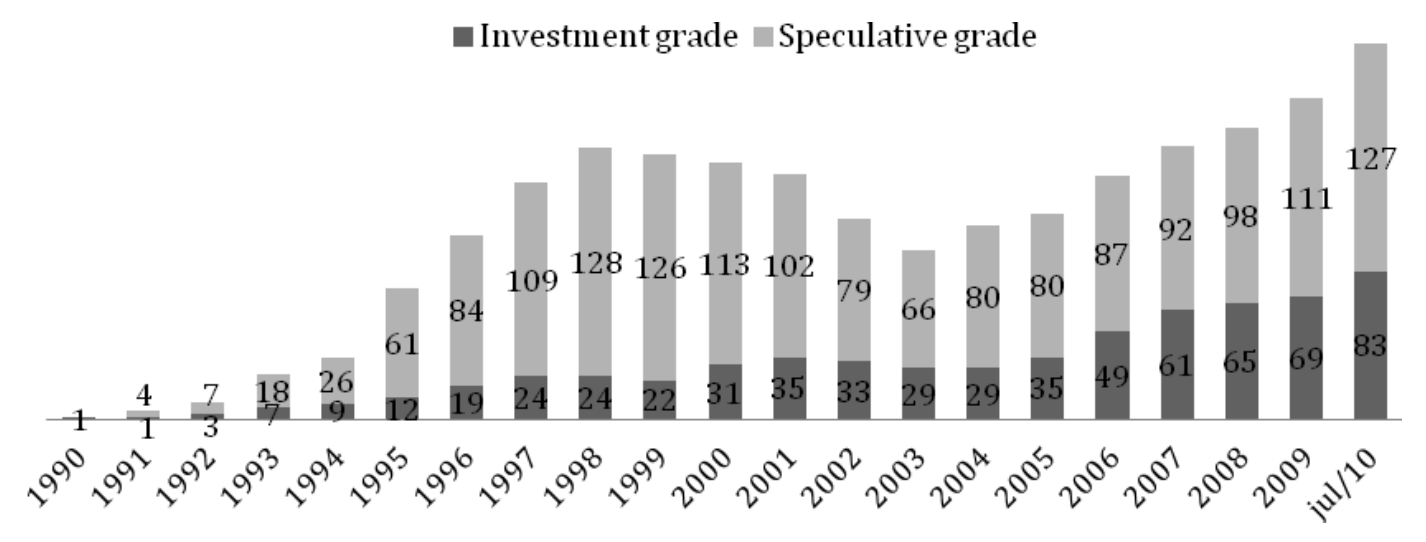

Figure 2. Evolution of Moody's Coverage in Latin America (July-1990/2010).

Source: Moody's Investors Service. (2010). Special comment: Latin american corporate default and recovery rates 1990-H1 2010. Retrieved from http:/www.alacrastore.com/research/moodys-global-credit-researchLatin_American_Corporate_Default_and_Recovery_Rates_1990_H1_2010_excel_data-PBC_127420

We decided to focus on the four major economies in Latin America instead of a single one. Many international investors, for instance pension funds and mutual funds, consider Latin America in their portfolio as a whole instead of a single country. By consolidating the four countries we examined a larger number of observations. It is also possible to analyze each country individually and compare similarities and differences in the way each one reacts to rating change announcements.

Some authors (Vassalou \& Xing, 2004) indicate that the cost of debt may increase due to rating downgrades. Minardi, Sanvicente and Artes (2007) develop a model for relating cost of debt to credit rating. The increased cost of this debt could influence stock prices (Jorion \& Zhang, 2007). However, as agencies are criticized for delaying credit rating changes in relation to financial markets, there is a question whether agency information is relevant to the market.

We intend to investigate whether the information provided by rating changes or Credit Watch announcements in Brazil, Mexico, Chile and Argentina impact investors' expectations and thus contribute to stock price appreciation or depreciation. According to Ee (2008), there are at least three reasons why equity reactions to credit rating change announcements in Latin America can differ to reactions in other regions. Corporate Governance (1) and regulatory issues (2) may differ from region to region and from country to country. Credit ratings are based on public and private information, and it is not clear if rating agencies can be as effective at collecting private information in Latin American countries as they are in developed countries (3).

Ee (2008) investigates how the equity markets of non-U.S. companies react to rating change announcements. Differently from his paper, we focus only on Latin American countries. We also enlarge the number of observations for Argentina, Brazil, Chile and Mexico, since we include data 
from 2008 and 2009, and we conduct significance testing for individual and consolidated countries.

The remainder of this article is organized as follows. Second section presents a literature review. Third section discusses the methodology and database. Fourth section discusses our findings. Finally, the fifth section concludes the work.

\section{Literature Review}

Several articles analyze credit-rating information in Latin America. Cisneros, Lizarzaburu and Salguero (2012) point out that the improvements in the regulatory environment in Peru, Chile and Colombia increase the quality and importance of rating agencies' credit risk reports. Minardi (2008) estimates Brazilian companies' default probabilities using the Black\&Scholes - Merton Model, compares them with Moody's mortality rates, and associates them with a credit rating. In most cases, S\&P's and Moody's credit ratings and ratings as estimated by stock prices coincide in terms of the rating's capital letter. The author interprets this as evidence that credit rating information is efficient in Brazil. Damasceno, Artes and Minardi (2008) do not reject the hypothesis that credit ratings are stable in Brazil and develop a credit-rating model based on financial ratios that predict $64 \%$ of S\&P's, Moody's and Fitch's credit ratings in Brazil.

Bone and Ribeiro (2009) examine the impact of rating changes in the Brazilian stock market during the period from 1995 to 2007 . They investigate if rating change announcements impact systematic risk measured by beta. They use the Chow stability test and find no evidence of structural breaks before or after the change.

The international literature investigates how credit rating changes impact publicly traded companies' share prices. Most authors find evidences that rating downgrades generate a significantly larger impact than rating upgrades (Dichev \& Piotroski, 2001; Goh \& Ederington, 1999).

Griffin and Sanvicente (1982) examine stock price changes in two periods: during the month of a rating change announcement and during the previous eleven months. The results indicate that downgrades convey information to shareholders, whereas upgrades result in minor price adjustments in the month of the rating adjustment. They observe that, in the case of upgrades, there is a positive abnormal return in the eleven months preceding the adjustment.

Jorion and Zhang (2007) study the effects of rating changes (1,195 downgrades and 361 upgrades) in senior unsecured debt in the U.S. corporate bonds market from January 1996 to May 2002. They find that the impact of downgrades tends to be larger than the impact of upgrades. One possible reason is that companies postpone the disclosure of negative information, but they immediately disclose positive information that may eventually result in a rating upgrade. They also point out that downgrades in speculative grade bonds significantly increase default probability and cost of capital, while downgrades in investment grade bonds create small fluctuations in default probability and cost of capital. Therefore downgrades in speculative issues more heavily impact price changes than downgrades in investment grade issues.

Table 1 shows the cumulative default rates in Latin America by Moody's rating category (Moody's, 2010). In line with the global pattern, Latin American companies rated Ba or less (i.e., speculative grade) tend to have very significant variations in default rates.

Jorion and Zhang (2007) analyze the effect of rating changes on stock returns by measuring the CAR (cumulative abnormal return). They examine a window from one year before until one year after $(-1$ year, +1 year) the announcing date, where $(0)$ is the effective date of the announcement. The sample of downgraded companies has an average CAR of $-4.43 \%$, which is statistically significant. For upgraded companies, the price change comes very close to zero $(\mathrm{CAR}=0.31 \%)$. However, they find a positive and significant average CAR for upgrades of speculative grade issues, although of a 
smaller magnitude than the downgrade impact.

Dichev and Piotroski (2001) analyze 4,700 changes in bond ratings by Moody's between 1970 and 1997. They find negative abnormal returns of between $10 \%$ and $14 \%$ in the first year after the announcement of downgrades, whereas for upgrades this abnormal return is less significant. Similar to Jorion and Zhang (2007), they observe that abnormal returns magnitudes are even higher for companies with low credit quality.

Table 1

Cumulative Default Rates between 1990 and July 2010: Latin America

\begin{tabular}{llllll}
\hline & Year 1 & Year 2 & Year 3 & Year 4 & Year 5 \\
\hline Aaa & $0.00 \%$ & $0.00 \%$ & $0.00 \%$ & $0.00 \%$ & $0.00 \%$ \\
\hline $\mathbf{A a}$ & $0.00 \%$ & $0.00 \%$ & $0.00 \%$ & $0.00 \%$ & $0.00 \%$ \\
\hline $\mathbf{A}$ & $0.00 \%$ & $0.00 \%$ & $0.00 \%$ & $0.00 \%$ & $0.00 \%$ \\
\hline Baa & $0.41 \%$ & $1.12 \%$ & $2.00 \%$ & $3.01 \%$ & $4.26 \%$ \\
\hline Ba & $0.27 \%$ & $1.37 \%$ & $4.04 \%$ & $8.61 \%$ & $12.04 \%$ \\
\hline Caa-C & $3.69 \%$ & $9.55 \%$ & $14.74 \%$ & $18.17 \%$ & $21.66 \%$ \\
\hline
\end{tabular}

Note. Source: Moody's Investors Service. (2010). Special comment: Latin American corporate default and recovery rates 1990-H1 2010. Retrieved from http://www.alacrastore.com/research/moodys-global-credit-researchLatin_American_Corporate_Default_and_Recovery_Rates_1990_H1_2010_excel_data-PBC_127420

Choy, Gray and Ragunathan (2006) study the impact of Moody's and S\&P ratings revisions of 63 companies on the Australian stock market between 1989 and 2003. Their results show a significant and negative impact for downgrades, and an insignificant impact for upgrades. According to them, companies very quickly disclose positive information, and stock prices immediately reflect such information, anticipating rating changes. The authors stressed, however, that their sample of upgrades is rather small, which may have impacted the results.

Ee (2008) studies the abnormal returns of Credit Watch and rating change announcements among companies outside of the United States. In a window between $(-1$ year, +1 year), the author finds significant negative cumulative abnormal returns for rating downgrades (CAR of $-1.33 \%$ ) and negative Credit Watch announcements (CAR of $-1.37 \%$ ). For upgrades and positive Credit Watch announcements, the CAR is not significant, at $0.07 \%$ and $0.13 \%$, respectively. As far as we are concerned, this article is the only one to mention the four countries we analyze: Argentina, Brazil, Chile and Mexico. Table 2 presents Ee's (2008) results for these four countries.

Table 2

Compilation of Ee's (2008) Results for Countries Considered in our Study

\begin{tabular}{lcccc}
\hline Country & $\begin{array}{c}\text { CAR } \\
\text { related to positive } \\
\text { Credit Watch }\end{array}$ & $\begin{array}{c}\text { CAR } \\
\text { related to negative } \\
\text { Credit Watch }\end{array}$ & $\begin{array}{c}\text { CAR } \\
\text { related to long-term } \\
\text { upgrades }\end{array}$ & $\begin{array}{c}\text { CAR } \\
\text { related to long-term } \\
\text { downgrades }\end{array}$ \\
\hline Argentina & $-0.30 \%$ & $-1.28 \%$ & $0.05 \%$ & $-2.87 \%$ \\
Brazil & $0.01 \%$ & $0.77 \%$ & $-1.28 \%$ & $-0.16 \%$ \\
Chile & $\mathrm{n} / \mathrm{a}$ & $-0.15 \%$ & $-0.53 \%$ & $-1.00 \%$ \\
Mexico & $-0.43 \%$ & $-2.30 \%$ & $0.05 \%$ & $-1.48 \%$ \\
\hline
\end{tabular}


Note. Source: Adapted from Ee, B. C. B. (2008). The impact of credit watch and bond rating changes on abnormal stock returns for Non-USA domiciled corporations (Master Thesis). Singapore Management University, Singapore. Retrieved from http://ink.library.smu.edu.sg/etd_coll/44

Overall, Ee (2008) finds negative returns for downgrades for the four countries, as expected. For positive and negative Credit Watches and upgrades, the signs of the CAR results did not show a pattern. He does not report t-tests for mean significance.

Linciano (2004) studies 299 rating actions of Italian companies by the three main rating agencies between January 1991 and August 2003. Unlike other authors, Linciano finds weak, negative abnormal returns for downgrades in the window between one day before and one day after the announcement. For upgrades, the results indicate significant positive abnormal returns after the change announcement.

Goh and Ederington (1999) find evidences that the market reacts much more negatively to downgrades to and within the speculative-grade category than it does to downgrades within the investment-grade category. The authors find no significant market reaction to upgrades.

Holthausen and Leftwich (1986) conducted studies of contaminated and uncontaminated samples. The latter sample involved the appearance during the event window of some information in addition to that published in the Wall Street Journal by the rating agency. The authors found that, for the contaminated samples, investors received new information from downgrades, and one of the most significant control variables was the change in rating level. For upgrades, the explanatory power of the regressions was low.

Ee (2008) finds that, for downgrades, the impact of CAR is even more negative for developed countries and for those downgrades crossing the border from investment grade to speculative grade. The author uses market capitalization as a proxy for size and, although it is significant, the coefficient is too small to have an impact on CAR. The reaction to negative Credit Watch announcements is negative and significant for firms located in developed countries.

\section{Methodology and Data}

We conduct an event study to investigate how rating changes and Credit Watch announcement impact Latin American companies' stock prices. We also run ordinary least square regressions to investigate what characteristics of rating changes explain the CAR, following the same reasoning used by Holthausen and Leftwich (1986). We investigate if downgrades from investment grade to speculative grade, upgrades form speculative grade to investment grade, and the number or rating notches in the upgrade or downgrade influence the magnitude of the CAR.

\section{Measurement of abnormal returns}

Camargos and Barbosa (2003) report three statistical models for determining abnormal returns: (a) constant mean-adjusted returns, (b) market-adjusted returns and (c) risk- and market-adjusted returns (market model).

We use, as suggested by Ee (2008), the market-adjusted return model. This model compares the returns of stock prices to the return of a benchmark, which is usually a stock index. This model assumes that asset returns are "simultaneously, normal, multivariate distributed independently and identically in time" (Camargos \& Barbosa, 2003, p. 8).

The market adjusted return model is a simplification of the market model. It assumes that alpha is zero and beta is one. It is not a strong assumption in our sample, since we estimate a mean beta of 0.92 and a median of 0.95 . Both mean and median for alpha is zero. This simplified model avoids 
estimation errors in calculating alphas and betas parameters. It also allows us to use more observations in computing abnormal returns. In order to estimate alphas and betas we need to have a reasonable number of days in which shares are traded in the estimation window. In a timeline, the estimation window comes before the event-window.

The market-adjusted return model is widely used in event studies and, according to Brown and Warner (1980) and Kloeckner (1995), gives a result that is quite similar to that of other models.

We calculate abnormal returns relative to specific benchmarks for each country in our sample. We use the IPSA for Chile; the IPC for Mexico; the Merval for Argentina; and, finally, the BOVESPA for Brazil.

\section{Definition of the event window}

We use an event window equal to fourteen days before (-14) and thirty days after $(+30)$ the date of a rating change announcement $(0)$.

According to Camargos and Barbosa (2003, p. 3), the choice of the window is arbitrary and "should not be too long, because it would risk encompassing other events, generating biases, nor too small, because it would risk failing to fully capture the abnormality in prices". The literature about market reaction to rating announcement does not have a consensus in the event window definition. Dichev and Piotroski (2001) check different event windows: 0 (date of the announcement) to 3 months, to 6 months, to 1 year, to 2 years and to 3 years after the announcement. Jorion and Zhang (2007) checked the event window of 1 year before to 1 year after the announcement. Ee (2008) tested different windows: 1 day before to 1 day after, 3 days before to 3 days after, 50 days before to 26 days before, 25 days before to one day before.

Some studies indicate that investors may anticipate (including insider trading in Ee (2008) or react to (Vassalou \& Xing, 2004) the rating change. We choose to analyze abnormal stock returns from 14 days before to 30 days after the event announcement. This window is not so far from the event day that it can be influenced by other news, but it is long enough to allow studying if there are anticipations and under-reactions to the rating announcement.

\section{Data}

We collect stocks' and indexes' daily closing prices and financial information for companies listed in four Latin American countries (Argentina, Brazil, Chile and Mexico) between 01/01/2000 and $12 / 31 / 2009$.

We select the sample based on the following criteria:

being a publicly traded company with shares held by the major stock indexes in their respective countries (IPSA in Chile, IPC in Mexico, Merval in Argentina and IBOVESPA in Brazil) as of $12 / 21 / 2010$.

having experienced changes in issuer ratings or foreign currency long-term ratings by any of the three major rating agencies between 01/01/2000 and 12/31/2009. Among the reasons we use issuer ratings rather than issue ratings is that issues may present some peculiarities such as guarantees or covenants that do not reflect the issuer credit quality as a whole.

We collect closing prices in USD (\$), adjusted for earnings, stock splits and dividends from the Economática ${ }^{\circledR}$ database. We collect changes in ratings and Credit Watch announcements from Bloomberg.

We do not include in the sample cases classified by S\&P as developing (except Klabin's rating change announced on 11/19/2002, which was effectively an upgrade). 
In the case of mergers, such as Fibria, a company resulting from the merger of Aracruz Celulose and Votorantim Celulose e Papel, we use the financial and price data adjusted by Economática ${ }^{\circledR}$ (VCPA4+FIBR3). In cases where a company listed on the stock exchange has more than one class of stock, we select the class with the highest average volume traded between 01/01/2000 and 12/31/2010.

We disregard rating changes of companies whose shares were not traded on dates close to the announcement. In cases where multiple agencies announce a rating change or Credit Watch on the same day we select the one that has the greatest absolute impact in terms of notches of grades. In order to promote data independency, we only consider the difference between the date of the last day of a first change and the date of the first day of a second change to be more than 74 calendar days. Our final sample contains 319 changes across the four countries.

Figures 3, 4, 5 and 6 show the distribution of downgrades, upgrades, negative Credit Watch and positive Credit Watch. Regarding the number of downgrades shown in Figure 3, there is a concentration during 2001, the year of the major downturn in Argentina's economy. Around 35-50\% of downgrades in Argentina and Brazil that were observed in our sample occurred in 2001. Brazil, by that time, was a non-investment grade country and Brazilian companies might have been impacted because of its economic links to Argentina.

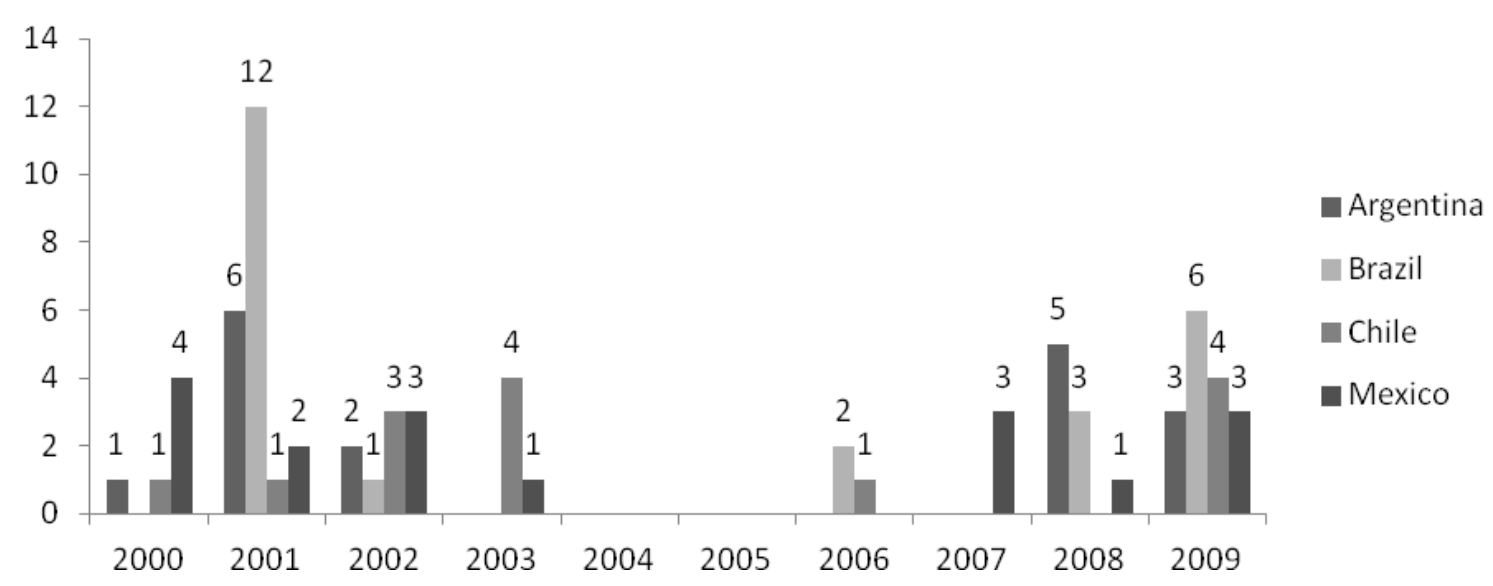

Figure 3. Distribution of Downgrades - Sample of 72. Source: authors' analysis.

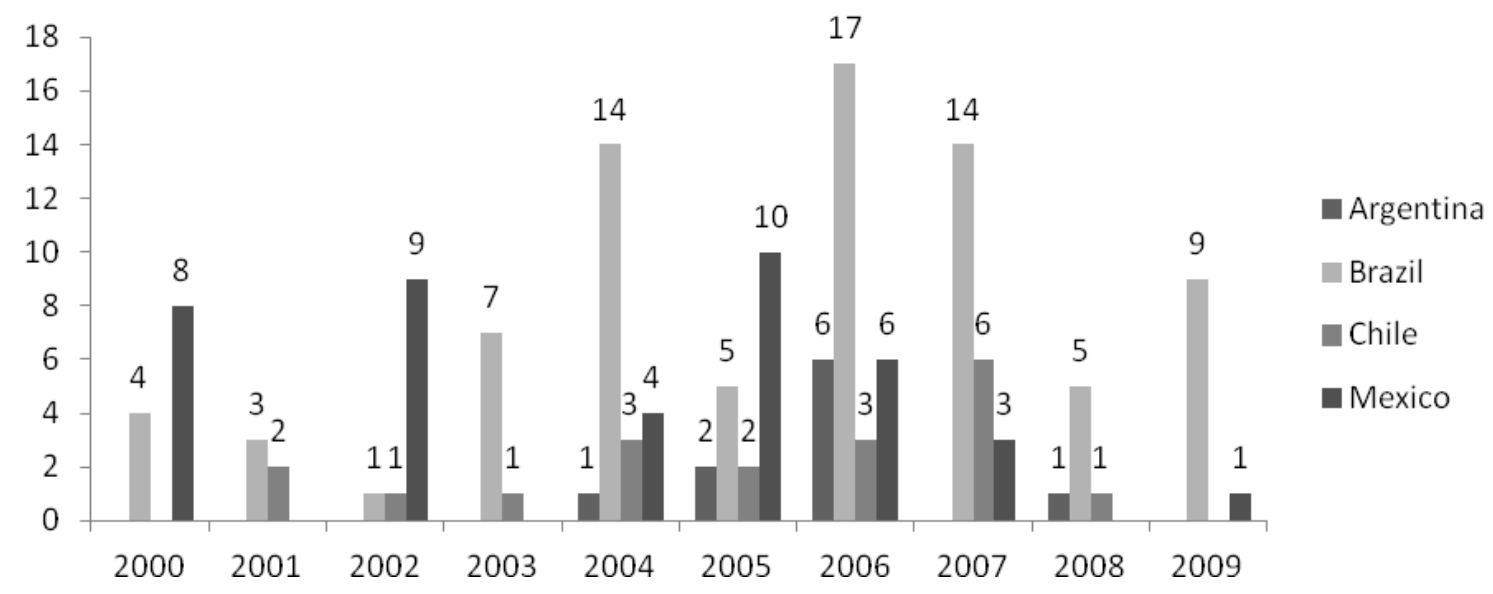

Figure 4. Distribution of Upgrades - Sample of 149.

Source: authors' analysis.

Figures 4 and 6 shows a more disperse distribution of upgrades and positive Credit Watch compared to downgrades, showing some concentration in 2004, 2005, 2006 and 2007, years that the regional economy was experiencing significant growth. 


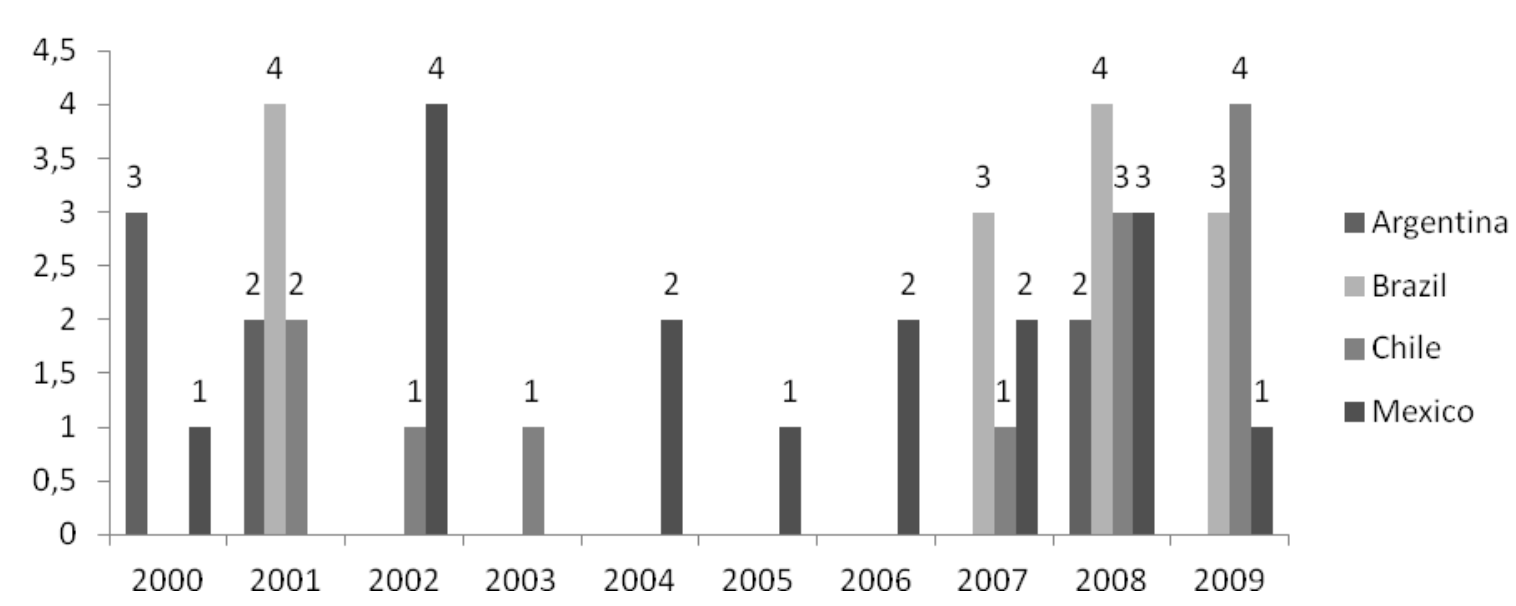

Figure 5. Distribution of Negative Credit Watch - Sample of 49. Source: authors' analysis.

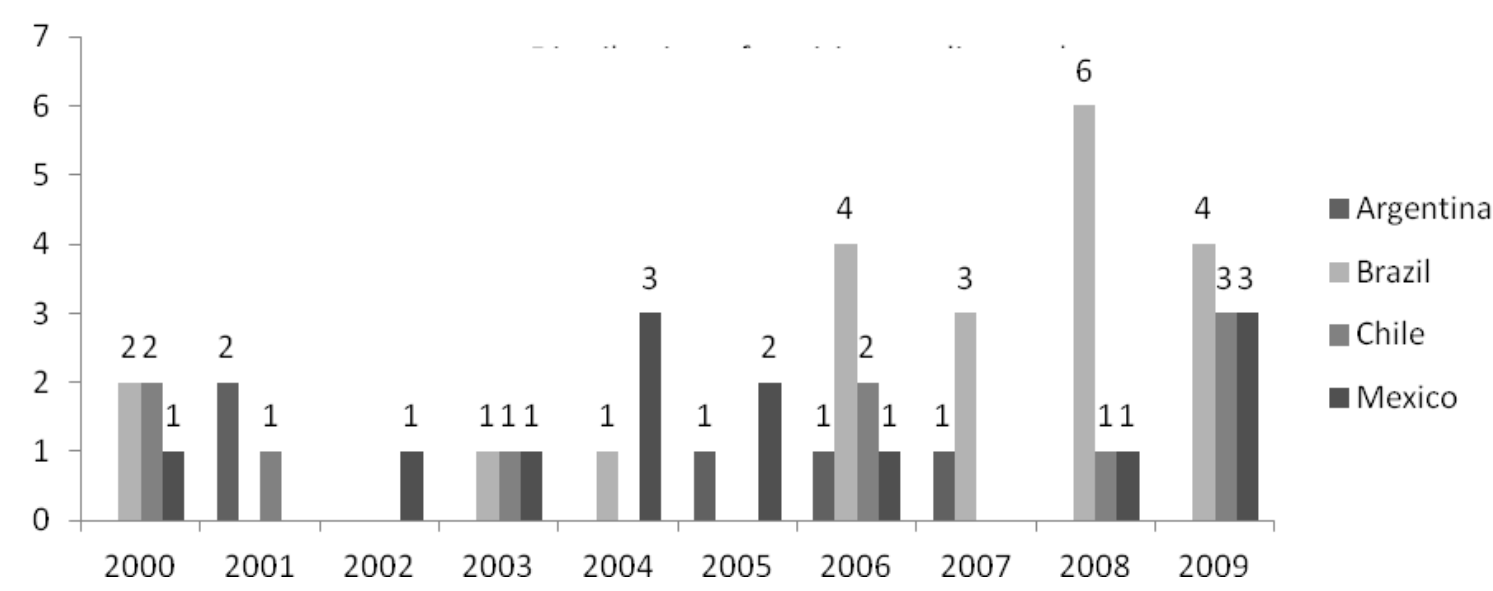

Figure 6. Distribution of Positive Credit Watch.

Source: authors' analysis.

In line with downgrades, negative Credit Watch announcements show a concentration during years of crisis: 2001, the debt crisis in Argentina, and 2008-2009, the sub-prime crisis.

Of the original ratings, almost $2 / 3$ of the sample is speculative grades: $5.2 \%$ are $\mathrm{A}, 30.3 \%$ are BBB, 33.1\% are BB, 27.5\% are B and 4\% are CCC-C. Only Chile and Mexico have companies with original ratings in the A category. Figure 7 contains a summary of the upgrades and downgrades in Latin America. We can observe that for each original rating, the majority of the migration is for 1 notch down, followed by 1 notch up. This is in accordance with the prudent migration discussed by Altman and Rijkent (2006), that agencies tend to make minor changes in rating grades. 


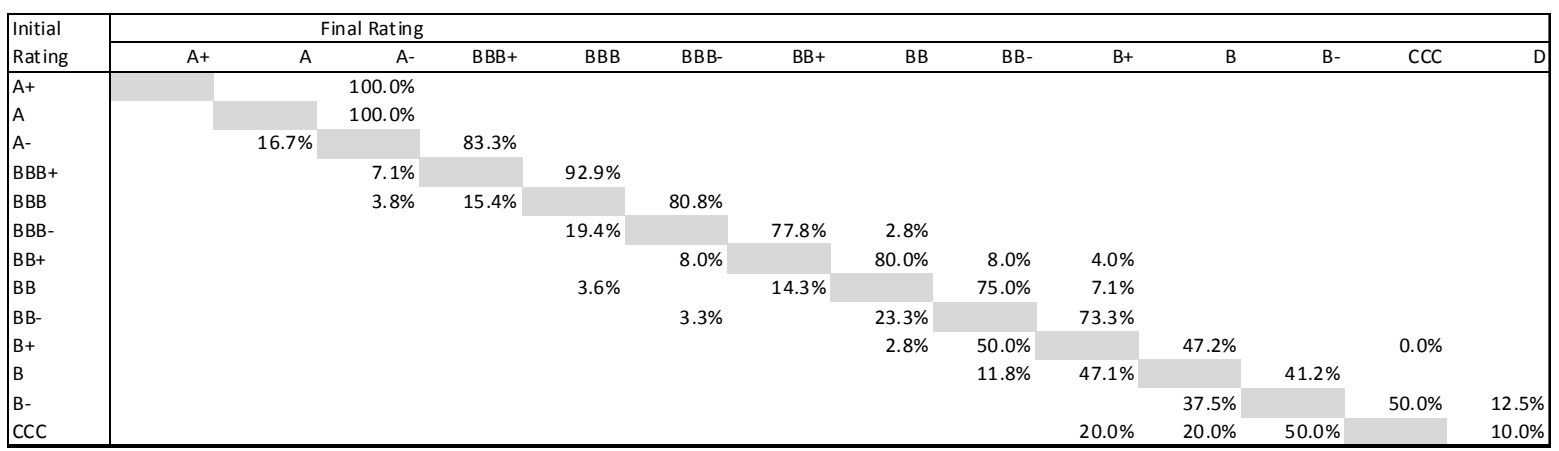

Figure 7. Rating Upgrades and Downgrades in Argentina, Brazil, Chile and Mexico, 2000-2009.

Source: authors' analysis.

\section{Procedures for calculating abnormal returns}

We adopt the methodology proposed by Campbell, Lo and Mackinlay (1997) to estimate abnormal returns. We calculate the return on each asset $i$ by equation 1 , where $\ln$ is the natural logarithm, $\mathrm{P}_{\mathrm{i}, \mathrm{t}}$ is the price of asset $\mathrm{i}$ on day $\mathrm{t}$ and $\mathrm{P}_{\mathrm{i}, \mathrm{t}-1}$ is the price of asset $\mathrm{i}$ on day $\mathrm{t}-1$.

$$
R_{i, t}=\ln \left(P_{i, t} / P_{i, t-1}\right)
$$

We calculate abnormal returns by equation (2), where $R_{i, t}$ and $R_{\text {index,t }}$ are the returns of asset $i$ on date $t$ and the return of the country index where the asset is found on date $t$, respectively.

$$
A R_{i, t}=R_{i, t}-R_{\text {index }, t}
$$

We use equation (3) to estimate the cumulative abnormal return.

$$
C A R_{i, T}=\sum_{i=0}^{T} A R_{i, t}
$$

We estimate the average CAR of samples according to equation (4), where $\mathrm{N}$ is the number of events (or changes). In this paper, when we mention CAR results, we are referring to the sample average CAR.

$$
\overline{C A R}_{i, T}=\frac{\sum_{i=1}^{n} C A R_{i, T}}{N}
$$

We define the null and alternative hypotheses to determine whether the calculated CAR is significant as follows:

- $\mathrm{H}_{0}$ : No abnormal return is observed in Latin American companies' stock prices in certain event windows after the announcement of a change in rating or Credit Watch.

- $\mathrm{H}_{\mathrm{A}}$ : An abnormal return is observed in Latin American companies' stock prices in certain event windows after the announcement of a change in rating or Credit Watch.

We find that CAR variance is:

$$
\operatorname{var}\left(\overline{C A R)}=\hat{\sigma}_{T}^{2} \times T\right.
$$


where $\hat{\sigma}_{T}$ is the standard deviation of a sample's mean abnormal return, and $\mathrm{T}$ is the number of days used for computing CAR .

The $t$-statistic test is calculated by equation (6).

$$
t-s t a t=\frac{\overline{C A R_{i, T}}}{\sqrt{\operatorname{var}(\overline{C A R})}}
$$

According to Campbell, Lo and MacKinlay (1997), we should use this type of test for investigating if a given event has any significant impact on the returns in the analyzed window.

We perform all of the calculations based on the following subgroups:

1. downgrade (all rating changes resulting in one notch or more downgrades, including when accompanied by changes in Credit Watch),

2. upgrade (all upward rating changes involving an elevation of a rating by one notch or more, including when accompanied by changes in Credit Watch),

3. negative Credit Watch (all downward changes by only one level due to a changing Credit Watch rating, without a notch change),

4. positive Credit Watch (all upward changes by only one level due to a changing Credit Watch rating, without a notch change),

5. changes from speculative to investment grade,

6. changes from investment to speculative grade,

7. individual analyses by country.

\section{Analysis of significant CAR determinants}

To determine which variables significantly determine CAR, we run White's heteroscedasticity robust multivariate regressions with qualitative and quantitative variables. The dependent variable is the CAR measured from 14 days before to thirty days after the event.

The financial and qualitative data used relate to the rating change date (0), and, whenever unavailable, we used the latest data.

We investigate the following variables:

1. size (represented by the logarithm of the market value in millions of US\$ or the logarithm of revenues in millions of US\$);

2. dummies identifying countries, with zero representing Brazil and each dummy indicating one to the other three countries;

3. dummies identifying changes crossing the investment-grade border;

4. leverage ratios (represented by Liabilities/Total Assets or Net Debt/EBITDA); and

5. a downgrade dummy interacting with the magnitude of the rating change.

The equation can be stated generically as follows: 


$$
\begin{aligned}
& \text { CAR }_{i, 30}=\beta_{0}+\beta_{1} * \text { LEVERAGE }+\beta_{2} * \text { LOG }(\text { SIZE })+\beta_{3} D O W N G R A D E * \text { VRATING }+ \\
& \beta_{4} *(1-D O W N G R A D E) * \text { VRATING }+\beta_{5} * D A R G+\beta_{6} * D M E X+ \\
& \beta_{7} * D C L+\beta_{8} * D S P I G+\beta_{9} * D I G S P+\varepsilon_{i}
\end{aligned}
$$

where:

- $C A R_{i, 30}$ : cumulative abnormal return from 14 days before until 30 days after each change $i$;

$\beta_{0}:$ regression intercept;

LEVERAGE: We expect a negative coefficient because the higher the leverage, the greater the risk of default and the more negative the impact should be on CAR. We use two different financial ratios to measure financial leverage.

LIABILITIES/A: total liabilities to total asset ratios.

D/EBITDA: net debt to EBITDA

- LOG(SIZE): The size of the company should be negatively correlated with CAR because larger companies are more visible and should be less impacted by a new classification (Elayan, Hsu, \& Meyer, 2003). We use two measures of size:

LOG(MKTCAP): logarithm of the company market value.

LOG(REVENUE): logarithm of company revenues.

DOWNGRADE: dummy variable assuming the value of 1 when a downgrade takes place. When the change is a Credit Watch announcement or upgrade, this variable assumes the value of zero. The expected sign for the coefficient is negative because the expected CAR is negative in a downgrade.

- VRATING: absolute change of ratings, calculated as the cardinal difference between the previous and the new ratings. This variable assumes the value of zero when there is only a Credit Watch change or when the change occurs within the subgroup of ratings indicating that a company is very close to default or has already defaulted.

. DARG: dummy variable assuming the value of 1 when the change applies to Argentina.

DMEX: dummy variable assuming the value of 1 when the change applies to Mexico.

. DCL: dummy variable assuming the value of 1 when the change applies to Chile.

- DSPIG: dummy variable assuming the value of 1 when the grade improves from speculative to investment grade. The coefficient of this variable should be positive because investors tend to purchase assets with lower credit risk.

DIGSP: dummy variable assuming the value of 1 when the grading declines from investment to speculative grade. The coefficient of this variable should be negative because investors tend to divest assets that are considered speculative.

The last two dummies of the equation (DSPIG and DIGSP) and the variable VRATING follow the same reasoning used by Jorion and Zhang (2007). The authors create a dummy that assumes a value of 1 when a rating change crosses the investment-speculative-grade border and 0 otherwise.

In addition, they use a variable measuring the magnitude of a rating change on a cardinal scale. For upgrades, the sign of this variable should be positive, indicating a positive effect on the return. The reverse should happen for downgrades. This paper uses the interaction between the dummy that 
identifies whether the change was a downgrade and the VRATING variable. For downgrades, the CAR is negative because the variable that reflects the change in ratings (VRATING) is negative and the dummy of downgrades is necessarily equal to one. Thus, for downgrades, the more negative the interaction between the two variables is, given that the coefficient is positive, the more negative CAR should become.

To transform the extent of a rating change into a quantitative variable, like Jorion and Zhang (2007) and Damasceno, Artes and Minardi (2008), we transform the credit rating into a cardinal scale, beginning with AAA as $1, \mathrm{AA}+$ as 2 , and so on. S\&P has ratings ranging from AAA to D, whereas Moody's uses a scale ranging from Aaa to $\mathrm{C}$. Table 3 displays the ratings by agency, interpretation and numerical scale.

Table 3

Ratings by Agency, Interpretation and Numerical Scale

\begin{tabular}{|c|c|c|c|c|c|c|c|c|c|}
\hline \multicolumn{5}{|c|}{ Investment Grade } & \multicolumn{5}{|c|}{ Speculative Grade } \\
\hline $\mathrm{S} \& \mathrm{P}$ & Fitch & Moody's & Interpretation & Numeric Scale & $\mathrm{S} \& \mathrm{P}$ & Fitch & Moody's & Interpretation & Numeric Scale \\
\hline AAA & AAA & Aaa & $\begin{array}{l}\text { Very high credit } \\
\text { quality }\end{array}$ & 1 & $\begin{array}{c}\mathrm{BB}+ \\
\mathrm{BB} \\
\mathrm{BB}-\end{array}$ & $\begin{array}{c}\mathrm{BB}+ \\
\mathrm{BB} \\
\mathrm{BB}-\end{array}$ & $\begin{array}{l}\mathrm{Ba} 1 \\
\mathrm{Ba} 2 \\
\mathrm{Ba} 3\end{array}$ & $\begin{array}{l}\text { It has speculative } \\
\text { elements } \\
\text { and it is subject to } \\
\text { substantial credit risk }\end{array}$ & $\begin{array}{l}11 \\
12 \\
13\end{array}$ \\
\hline $\begin{array}{l}\mathrm{AA}+ \\
\mathrm{AA} \\
\mathrm{AA}-\end{array}$ & $\begin{array}{l}\mathrm{AA}+ \\
\mathrm{AA} \\
\mathrm{AA}-\end{array}$ & $\begin{array}{l}\text { Aa1 } \\
\text { Aa2 } \\
\text { Aa3 }\end{array}$ & High credit quality & $\begin{array}{l}2 \\
3 \\
4\end{array}$ & $\begin{array}{l}\mathrm{B}+ \\
\mathrm{B} \\
\mathrm{B}-\end{array}$ & $\begin{array}{c}\mathrm{B}+ \\
\mathrm{B} \\
\mathrm{B}-\end{array}$ & $\begin{array}{l}\mathrm{B} 1 \\
\mathrm{~B} 2 \\
\mathrm{~B} 3\end{array}$ & $\begin{array}{l}\text { It is considered } \\
\text { speculative } \\
\text { and it has high } \\
\text { credit risk }\end{array}$ & $\begin{array}{l}14 \\
15 \\
16\end{array}$ \\
\hline $\begin{array}{l}\mathrm{A}+ \\
\mathrm{A} \\
\mathrm{A}-\end{array}$ & $\begin{array}{c}\mathrm{A}+ \\
\mathrm{A} \\
\mathrm{A}-\end{array}$ & $\begin{array}{l}\text { A1 } \\
\text { A2 } \\
\text { A3 }\end{array}$ & $\begin{array}{l}\text { Medium-high } \\
\text { grade, } \\
\text { with low credit } \\
\text { risk }\end{array}$ & $\begin{array}{l}5 \\
6 \\
7\end{array}$ & $\begin{array}{c}\mathrm{CCC}+ \\
\mathrm{CCC} \\
\mathrm{CCC}- \\
\mathrm{CC}\end{array}$ & $\begin{array}{c}\mathrm{CCC}+ \\
\mathrm{CCC} \\
\mathrm{CCC}- \\
\mathrm{CC}\end{array}$ & $\begin{array}{c}\mathrm{Caa} 1 \\
\mathrm{Caa} 2 \\
\mathrm{Caa} 3 \\
\mathrm{Ca}\end{array}$ & $\begin{array}{c}\text { Bad credit conditions and } \\
\text { it is subject to high credit } \\
\text { risk }\end{array}$ & $\begin{array}{l}17 \\
18 \\
19 \\
20\end{array}$ \\
\hline $\begin{array}{l}\mathrm{BBB}+ \\
\mathrm{BBB} \\
\mathrm{BBB}-\end{array}$ & $\begin{array}{l}\mathrm{BBB}+ \\
\mathrm{BBB} \\
\mathrm{BBB}-\end{array}$ & $\begin{array}{l}\text { Baa1 } \\
\text { Baa2 } \\
\text { Baa3 }\end{array}$ & $\begin{array}{l}\text { Moderate Credit } \\
\text { Risk }\end{array}$ & $\begin{array}{c}8 \\
9 \\
10\end{array}$ & $\begin{array}{c}\text { C } \\
\text { SD } \\
\text { D } \\
-\end{array}$ & $\begin{array}{c}\text { C } \\
\text { DDD } \\
\text { DD } \\
\text { D }\end{array}$ & $\begin{array}{l}\mathrm{C} \\
-\end{array}$ & $\begin{array}{l}\text { Very close } \\
\text { to default } \\
\text { or in default }\end{array}$ & $\begin{array}{l}22 \\
22 \\
22 \\
22\end{array}$ \\
\hline
\end{tabular}

Note. Source: Adapted from Damasceno, D. L., Artes, R., \& Minardi, A. M. A. F. (2008). Determinação de rating de crédito de empresas brasileiras com a utilização de índices contábeis. Revista de Administração da Universidade de São Paulo, 43(4), 344-355.

\section{Results}

Our sample consists of 319 rating changes or Credit Watch announcements, with 39 in Argentina, 138 in Brazil, 55 in Chile and 87 in Mexico. Brazil and Mexico are the two largest capital markets, have the majority of companies covered by rating agencies and a higher number of observations in our sample.

\section{Average CAR}

Figure 8 shows the average CAR behavior for upgrades and downgrades across the time window analyzed. We can observe that the market anticipates downgrades and continues to react after the announcement. This evidence is consistent with Goh and Ederington (1999).

In the case of downgrades, CAR starts to be significant at the $10 \%$ level 9 days before the event, at the $5 \%$ level 4 days before and at the $1 \%$ level 1 day before announcement. This fact is in line with the arguments of Servigny and Renault (2004) and Altman and Rijken (2006). According to these 
authors, rating agencies adopt a conservative approach by granting through-the-cycle rating grades. Therefore rating changes may capture credit quality deterioration with a certain time lag.

Many institutional investors have a policy of only keeping investment-grade bonds in their portfolios. One possible reason why the CAR continues to be very significant after the downgrade announcement is the existence of downgrades crossing the investment-grade to speculative-grade border. However, when we exclude the four changes from investment to speculative grade, the magnitude of CAR decreases, but it remains very significant at the $1 \%$ level after 30 days (CAR=$7.2 \%$, $t$-stat $=-7.5$ ). We interpret this finding as evidence of under-reaction to rating downgrade news. One possible explanation is that some investors, pension funds for instance, also have committees to decide whether to increase or decrease the allocation in a certain security, and this may create a time lag between downgrades announcements and portfolio rebalancing.

For upgrades, the average CAR remains around $0 \%$ without showing a clear pattern for up to 21 days after the upgrade, when it starts to present a positive average CAR, but remains very close to zero and without significance.

According to Ederington and Goh (1998), the different market reactions to upgrades and downgrades can be explained by the fact that positive news are disseminated more quickly than negative news and, therefore, the impact of positive news on stocks is absorbed sooner. Another possible explanation raised by the authors is that rating agencies invest more resources in the search for causes of deterioration in companies' financial situations than they do for causes of credit enhancements. When a rating agency puts more effort into finding evidence of companies' worsening abilities to pay, one expects to find evidence that the market has not yet observed, which would explain why agencies bring new information for downgrades.

Table 4 summarizes the average CAR results for downgrades and upgrades, respectively, by country and consolidated, with their respective t-statistics, between 14 days before the event and 30 days after it.

For downgrades, we observe a CAR of $-7.86 \%$, which is highly significant at the $1 \%$ level. We reject the null hypothesis that an abnormal return of Latin American companies' stock prices is not observed for downgrades.

For the countries studied, the reactions to the news are negative and significant at the $5 \%$ level, except for Argentina, which shows a non-significant negative reaction.

For upgrades, we observe a non-significant average CAR of $0.51 \%$, which is a smaller impact compared to that of downgrades. In general, there are more upgrades than downgrades in our sample, thus demonstrating recent improvements in the region's credit score. Whereas Argentina shows more downgrades than upgrades during the analyzed period (17 downgrades and 10 upgrades), Brazil, Chile and Mexico combined had 55 downgrades and 139 upgrades. 


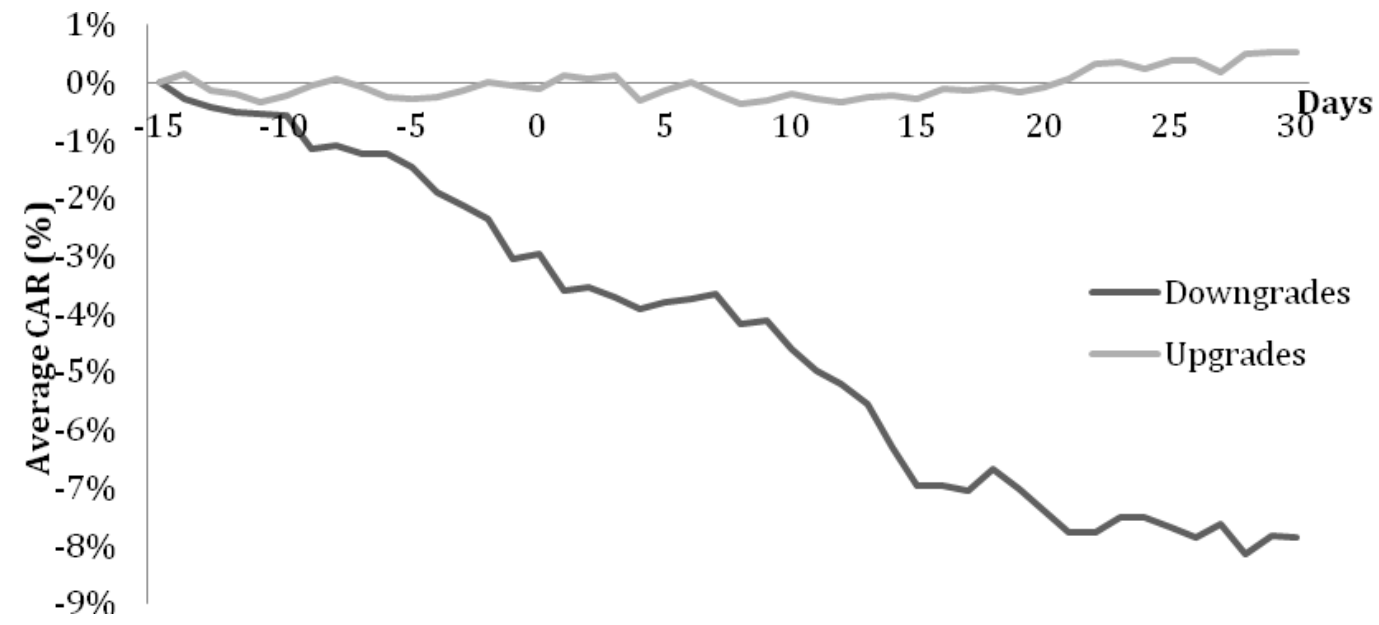

Figure 8. Average CAR Evolution for Downgrades and Upgrades in the Sample.

Source: authors' analysis.

Although the consolidated results are similar to the findings of previous studies, when we analyze the CAR for each individual country, Table 4 shows different behavior for upgrades. For both Argentina and Chile, investors seem to be impacted by upgrade announcements because the CAR is positive and significant. For Brazil and Mexico, the negative CAR is counterintuitive, but both are close to zero and non-significant.

Table 4

CAR (+30) for Downgrades and Upgrades by Country and Across all 4 Countries

\begin{tabular}{ccccc}
\hline Country & Downgrade & Obs. & Upgrade & Obs. \\
\hline Argentina & $-1.22 \%$ & 17 & $6.32 \%$ & 10 \\
& $(-0.31)$ & & $\left(1.25^{*}\right)$ & \\
\multirow{2}{*}{ Brazil } & $-6.35 \%$ & 24 & $-0.86 \%$ & 79 \\
& $\left(-1.87^{* *}\right)$ & & $(-0.61)$ & 19 \\
Chile & $-9.09 \%$ & 14 & $4.87 \%$ & 41 \\
& $(-3.29 * * *)$ & & $(1.80 * *)$ & \\
Mexico & $-15.64 \%$ & 17 & $-0.28 \%$ & 149 \\
& $\left(-3.23^{* * *}\right)$ & & $(-0.14)$ & \\
\hline \multirow{2}{*}{ Total } & $-7.86 \%$ & 72 & $0.51 \%$ & $(0.52)$ \\
\end{tabular}

Note. T-statistics are shown in parentheses.

*** refers to abnormal returns significantly different from zero at $1 \%$ significance; ** refers to abnormal returns significantly different from zero at $5 \%$ significance; * refers to abnormal returns significantly different from zero at $10 \%$ significance.

With respect to changes in Credit Watch (positive and negative), Figure 9 shows the average CAR evolution for the whole sample, and Table 5 summarizes the results by country and consolidated, with their respective t-statistics.

Even if a Credit Watch announcement is a short- or medium-term indication of possible rating changes, the consolidated results in our sample do not show a clear trend of behavior for either positive or negative Credit Watch (Figure 9) and indicate that investors' information is still insufficient to significantly impact the CAR within 30 days after the event. 
For negative Credit Watch announcements, the results are generally different from those found by Ee (2008), where the observed CAR is significant, though less significant for developing countries compared to developed countries.

For the 30 days after the change, the signs are as expected and in line with the results presented by Ee (2008), though both results are non-significant. In our sample, in the case of negative Credit Watch announcements, the CAR has a negative sign during the period (CAR average of $-0.26 \%$ ); for positive Credit Watch announcements, the sign of the CAR is positive (average CAR of $0.41 \%$ ).

When the analysis is done by country, the effect of a negative Credit Watch announcement is not significant for any country in the window between $(-14,+30)$.

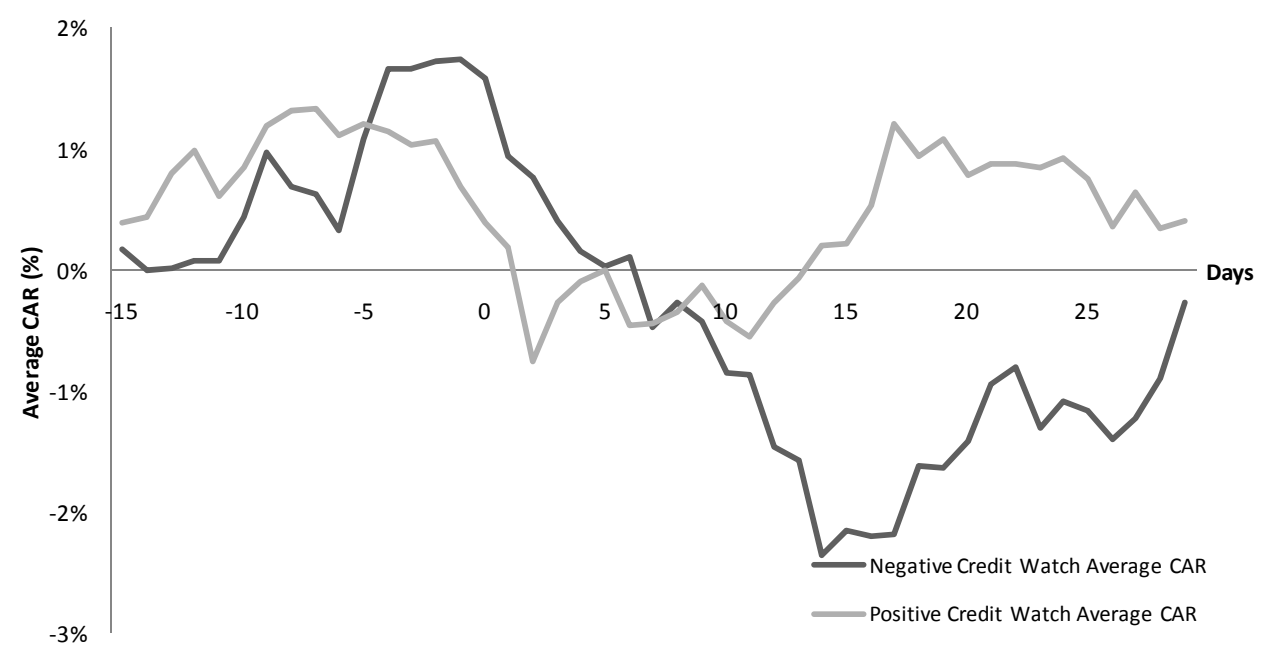

Figure 9. Average CAR Evolution for Negative and Positive Credit Watch Announcements in the Sample.

Source: authors' analysis.

Table 5 shows that, for positive Credit Watch announcements, the average CAR is not significant for any of the four countries. Despite the small sample size, for Argentina the positive Credit Watch announcements unexpectedly resulted in a CAR of $-5.71 \%$. We do not report the tstatistic for positive Credit Watch announcements in Argentina due to the low number of observations.

Table 6 shows the consolidated results of CAR for changes that crossed the investment-grade barrier. Despite the small sample size, of the 28 observations of changes from investment grade to speculative grade, the average CAR is $2.7 \%$ and significant.

This impact is even larger in absolute terms when analyzing changes from investment to speculative grade. The average CAR for the four observations of such a change was $-19.22 \%$, but due to the small number of observations, no significance test was performed. This reaction shows the effect of an investment-grade rating, as described by Jorion and Zhang (2007), wherein investors tend to divest stocks of speculative-grade companies and buy stocks of investment-grade companies. Pension funds and institutional investors often have a policy of investing only in investment grade securities. Therefore, when a company is downgraded to speculative grade, investors are forced to sell issues of this issuer for not fitting into internal investment policies. This explanation would account for the trend of negative reactions of the CAR to downgrades and positive reactions to upgrades. 
Table 5

CAR (+30) for Negative (-1) and Positive (+1) Credit Watch Announcements by Country and for the Sample as a Whole

\begin{tabular}{ccccc}
\hline Country & $\begin{array}{c}\text { Negative Credit } \\
\text { Watch }\end{array}$ & Obs. & $\begin{array}{c}\text { Positive Credit } \\
\text { Watch }\end{array}$ & Obs. \\
\hline Argentina & $-2.53 \%$ & 7 & $-5.71 \%$ & 5 \\
& $(-0.42)$ & & N/A & \\
Brazil & $0.19 \%$ & 14 & $1.95 \%$ & 21 \\
& $(0.04)$ & & $(0.30)$ & 10 \\
Chile & $-1.26 \%$ & 12 & $0.33 \%$ & 13 \\
& $(-0.27)$ & & $(0.11)$ & \\
Mexico & $1.08 \%$ & 16 & $1.79 \%$ & 49 \\
& $(0.29)$ & 49 & $(0.47)$ & \\
Total & $-0.26 \%$ & & $0.41 \%$ & $(0.51)$ \\
\end{tabular}

Note. T-statistics are shown in parentheses.

Table 6

CAR (+30) for Changes that Cross the Investment-grade Barrier

\begin{tabular}{lccc}
\hline Change & CAR (-14.+30) & t-statistic & Observations \\
\hline From speculative to investment grade & $2.70 \%$ & $1.16^{*}$ & 28 \\
From investment to speculative grade & $-19.22 \%$ & N/A & 4 \\
\hline
\end{tabular}

Note. ${ }^{* *}$ refers to abnormal returns significantly different from zero at $5 \%$ significance.

\section{Robustness checks}

We conduct three robustness checks: (a) we changed the length of the event window; (b) we excluded downgrades announced in 2001 from the sample; and (c) we estimated CAR using market model instead of market adjusted returns.

We investigate three different event windows: $(-1,+1),(-2,+2)$ and $(-3,+3)$, and the tests validate that stock markets in Latin America reacts negatively to downgrades and ignore upgrades. For downgrades, we find a CAR equal to $-1.23 \%$ for the event window $(-1,+1)$, equal to $-1.40 \%$ for $(-2$, $+2)$ and equal to $-1.82 \%$ for $(-3,+3)$, and all three results are significant at the $1 \%$ level. For upgrades, we find a CAR equal to $0.11 \%$ for the window $(-1,+1)$, equal to $0.20 \%$ for $(-2,+2)$ and equal to $0.36 \%$ for $(-3,+3)$, and all three results are insignificant.

We excluded 2001 events from the sample, because there was a concentration of downgrades, especially for Argentina and Brazil (see Figure 3), and we estimated a CAR for 30 days after the event of $-8.7 \%$, significant at the $1 \%$ level, confirming our previous findings.

We also estimated CAR using the market model, calculating the abnormal return as follows.

$$
A R_{i, t}=R_{i, t}-\left(\alpha_{i}+\beta_{i} R_{\text {index }, t}\right)
$$


For estimating the parameters alpha and beta we use an estimation window of 252 days before the event window. The average $\alpha$ was 0 , with median 0 and the average $\beta$ was 0.92 , with median 0.95 . Our results confirm a negative CAR for 30 days after the event equal to $-4,00 \%$, significant at the $2 \%$ level, starting to be negative and significant 10 days before the announcement, and with significant under-reaction to 30 days after. We also find insignificant results for upgrades, confirming our findings with the market-adjust returns model.

\section{Determinants of the CAR for Latin American stocks by changes in rating}

Table 7 summarizes the results of four regressions with cross-sectional data investigating which variables (qualitative and/or quantitative) significantly explain the reaction of the stock price to the event of a credit rating change.

Models 1 and 2 use the interaction of the dummy variable for downgrades and the absolute change in ratings as an explanatory variable. The differences between the two models lie in the use of different leverage ratios (model 1 uses the Total Liabilities/Assets and model 2 uses Net Debt/EBITDA) and different size indicators (model 1 uses the logarithm of market value, whereas model 2 uses the logarithm of revenue). In both models, we find results consistent with Holthausen and Leftwich (1986), where the most significant variable is the interaction between the downgrade dummy and the change in absolute rating, which results in a highly significant positive coefficient as expected. In the case of downgrades, the greater the negative change of ratings is, the more negative the average CAR tends to be, possibly because companies with a declining ability to meet their financial commitments tend to pay higher interest rates for loans, decreasing the cash flow to shareholders.

For changes other than downgrades, the interaction between (1-DOWNGRADE) and VRATING is non-significant.

Note that the net debt/EBITDA ratio in model 2 is positively significant to CAR, and therefore the more leveraged the issuer, the stronger the market reaction to rating announcements.

The basic difference between models 1 and 2 and models 3 and 4 lies in the latter's use of dummies identifying changes that cross the investment-grade border as a result of both downgrades and upgrades, instead of the interaction between the dummy of downgrades and the absolute change in the rating. These dummies contribute the most to explaining the CAR in these models and have the expected signs: they are negative when the change is from investment to speculative grade and positive when the change is from speculative to investment grade.

We observe that, for both model 3 and model 4, the dummies identifying downgrades from investment to speculative grade are more significant than the dummies identifying upgrades from speculative to investment grade. This result is consistent with the argument that the average CAR has a larger impact when it is a downgrade.

In all models, the constant is not significant, nor are the dummy variables identifying the country or the variables indicating company size.

The second model demonstrates the greatest explanatory power because it has the highest adjusted $\mathrm{R}^{2}$ and lowest probability (F-statistic), indicating that the variables are jointly significant. Models 3 and 4 do not have good explanatory power because they have low adjusted $\mathrm{R}^{2}$ and probability (F-statistic) greater than $10 \%$. 
Table 7

Sensitivity of CAR in the Latin American Stock Market to Qualitative and Quantitative Variables - Models 1, 2, 3 and 4

\begin{tabular}{|c|c|c|c|c|}
\hline & Model 1 & Model 2 & Model 3 & Model 4 \\
\hline Variables & Coefficient/t-stat & Coefficient/t-stat & Coefficient/t-stat & Coefficient/t-stat \\
\hline $\boldsymbol{\beta}_{0}$ & $\begin{array}{l}-0.029 \\
(-0.277)\end{array}$ & $\begin{array}{c}0.058 \\
(0.526)\end{array}$ & $\begin{array}{l}-0.098 \\
(-0.941)\end{array}$ & $\begin{array}{c}0.029 \\
(0.249)\end{array}$ \\
\hline LIABILITIES/A & $\begin{array}{c}-0.000 \\
(-0.401)\end{array}$ & - & $\begin{array}{l}-0.000 \\
(-0.542)\end{array}$ & - \\
\hline D/EBITDA & - & $\begin{array}{c}0.000 \\
(2.127)^{* *}\end{array}$ & - & $\begin{array}{c}0.001 \\
(3.577)\end{array}$ \\
\hline LOG(MKTCAP) & $\begin{array}{c}0.002 \\
(0.298)\end{array}$ & - & $\begin{array}{c}0.006 \\
(0.968)\end{array}$ & - \\
\hline LOG(REVENUE) & - & $\begin{array}{l}-0.004 \\
(-0.614)\end{array}$ & - & $\begin{array}{l}-0.004 \\
(-0.483)\end{array}$ \\
\hline $\begin{array}{l}\text { DOWNGRADE * } \\
\text { VRATING }\end{array}$ & $\begin{array}{c}0.054 \\
(2.736)^{* * *}\end{array}$ & $\begin{array}{c}0.082 \\
(4.224)^{* * *}\end{array}$ & - & - \\
\hline $\begin{array}{l}\text { (1-DOWNGRADE) } \\
\text { VRATING }\end{array}$ & $\begin{array}{c}0.013 \\
(1.191)\end{array}$ & $\begin{array}{c}0.005 \\
(0.544)\end{array}$ & - & - \\
\hline DARG & $\begin{array}{c}0.039 \\
(1.277)\end{array}$ & $\begin{array}{c}0.000 \\
(0.008)\end{array}$ & $\begin{array}{c}0.029 \\
(0.934)\end{array}$ & $\begin{array}{c}-0.014 \\
(-0.435)\end{array}$ \\
\hline DCL & $\begin{array}{c}0.016 \\
(0.712)\end{array}$ & $\begin{array}{c}0.023 \\
(0.979)\end{array}$ & $\begin{array}{c}0.017 \\
(0.758)\end{array}$ & $\begin{array}{c}0.018 \\
(0.714)\end{array}$ \\
\hline DMEX & $\begin{array}{c}-0.006 \\
(-0.335)\end{array}$ & $\begin{array}{c}-0.002 \\
(-0.097)\end{array}$ & $\begin{array}{c}-0.006 \\
(-0.355)\end{array}$ & $\begin{array}{c}-0.003 \\
(-0.154)\end{array}$ \\
\hline DSPIG & - & - & $\begin{array}{c}0.042 \\
(1.722)^{*}\end{array}$ & $\begin{array}{c}0.054 \\
(1.879)^{*}\end{array}$ \\
\hline DIGSP & - & - & $\begin{array}{c}-0.172 \\
(-2.837)^{* * *}\end{array}$ & $\begin{array}{c}-0.172 \\
(-2.916)^{* * *}\end{array}$ \\
\hline $\mathbf{R}^{2}$ & 0.071 & 0.116 & 0.037 & 0.043 \\
\hline Adjusted $\mathbf{R}^{2}$ & 0.050 & 0.093 & 0.015 & 0.017 \\
\hline F-statistic & 3.395 & 4.973 & 1.709 & 1.686 \\
\hline Prob(F-statistic) & $0.002 * * *$ & $0.000 * * *$ & 0.106 & 0.113 \\
\hline Sample & 318 & 272 & 318 & 272 \\
\hline
\end{tabular}

Note. Variables used in the models: $\beta_{0}$ : regression constant. LIABILITIES/A: the ratio of total liabilities to total assets. D/EBITDA: Net Debt to EBITDA ratio, which indicates the number of periods of operational cash flow creation of a company to cover the debt position minus the cash position. LOG(MKTCAP): logarithm of market value. LOG(Revenue): logarithm of revenue. DOWNGRADE: dummy variable assuming the value 1 for a downgrade. VRATING: absolute variation of ratings, representing the cardinal difference between the previous and the new ratings. Assumes the value zero when there is only a Credit Watch change or when the change occurs within the subset of ratings that indicate that the company is very near or already in default. DARG: dummy variable assuming the value 1 when the change refers to Argentina. DMEX: dummy variable assuming the value 1 when the change refers to Mexico. DCL: dummy variable assuming the value 1 when the change refers to Chile. DSPIG: dummy variable assuming the value 1 when the rating changes from speculative to investment grade. DIGSP: dummy variable assuming the value 1 when the rating changes from investment to speculative grade.

T-statistics are shown in parentheses. $* * *$ refers to abnormal returns different from zero at $1 \%$ significance; $* *$ refers to abnormal returns different from zero at 5\% significance; * refers to abnormal returns different from zero at $10 \%$ significance. 


\section{Conclusions}

Our objective is to investigate stock market behavior in Argentina, Brazil, Chile and Mexico when a rating change or Credit Watch occurs and to identify variables that might help to explain the magnitude of investors' reaction to the news. We use cumulative abnormal return (CAR) to measure market reaction to news.

Consistent with much of the international literature, we find that during the event window around the date of a downgrade, the stock prices of publicly traded companies in these countries in general (and also most of the specific companies) experience considerable negative returns. We can observe negative reaction both before the rating change date, which can be explained by the conservatism of the rating agencies (Servigny \& Renault, 2004), and after the change, which can be explained by market under-reaction, possibly arising from a lower free cash flow to equity after a downgrade, which would increase the cost of funding the company and the time institutional investors may take to decide to divest a certain company's stock.

For upgrades, although the average CAR is positive, we find no evidence of a significant impact on stock prices. Among the possible explanations for the difference in the magnitudes of CAR for downgrades and upgrades is that companies disclose positive data immediately. The same does not occur with negative news. In addition, rating agencies may make more of an effort to find evidence, unobserved by the market, supporting a downgrade. Such evidence would decrease the company's credit quality; thus, the downgrade provides investors with new information.

We also note that, for positive or negative Credit Watch changes, the impact is not as significant as the impacts observed for downgrades; however, between $(-14,+30)$, the sign of CAR is as expected. Although there is little research assessing the impact of Credit Watch announcements, particularly when they are positive, our results are consistent with those reported by Ee (2008). In the countries included in the sample, Credit Watch disclosure might be less informative because investors would prefer to wait for the change in rating. The rating agencies may not yet be equipped with all necessary information to issue a conclusive opinion when they issue the Credit Watch.

We also find that the CAR is higher in absolute terms when there are rating changes crossing the investment-grade/speculative-grade border.

With respect to the regressions, we find that the absolute change in ratings during a downgrade is significantly related to CAR.

Sample size is a limitation, especially because there are very few data for downgrades and upgrades crossing the investment grade to speculative grade border. Although using CAR as a dependent variable in cross section regression is usual in the literature, the result may be biased, because CAR is measured with errors. According to Cochrane (2005), the method of least squares corrected by White heterocedasticity robust approach may yield consistent estimates but is not efficient if the errors are not independent and identically distributed. Our results show evidences that, like other countries, credit ratings are relevant information in Argentina, Brazil, Chile and Mexico, especially in rating downgrades. It contributes to a better understanding of investors' behavior. Many institutional investors divest securities of companies that are downgraded by rating agencies. Moreover, because the development of the Latin American capital markets and the increased coverage by rating agencies are relatively recent, the present study is one of the few to provide more data on the impact of ratings in these four countries. The issue concerning the relevance of credit rating is crucial, because the Bale Agreement suggests agency credit ratings as one of the inputs in the internal models for assessing financial institution credit risk. 


\section{References}

Altman, E. I., \& Rijkent, H. A. (2006). A point-in-time perspective on through-the-cycle ratings. Financial Analyst Journal, 62(1), 54-70.

Bone, R. B., \& Ribeiro, E. P. (2009, julho). Conteúdo informacional dos ratings corporativos de empresas brasileiras, 1995-2007. Proceedings of the Brazilian Finance Meeting. São Leopoldo, Brazil, 9.

Brown, S. J., \& Warner, J. B. (1980). Measuring security price performance. Journal of Financial Economics, 8(3), 205-258. doi: 10.1016/0304-405X(80)90002-1

Camargos, M. A., \& Barbosa, F. V. (2003). Estudo de evento: teoria e operacionalização. Cadernos de Pesquisa em Administração, 10(3), 1-20.

Campbell, J. Y., Lo, A. W., \& Mackinlay, A. C. (1997). The econometrics of financial markets. New Jersey, EUA: Princeton University Press.

Choy, E. Y. W., Gray, S. F., \& Ragunathan, V. (2006). Effect of credit rating changes on australian stock returns. Accounting and Finance, 46(5), 755-769. doi: 10.1111/j.1467-629X.2006.00192.x

Cisneros, D., Lizarzaburu, E. R., \& Salguero, J. Q. (2012). Credit information in emerging markets: the rating agencies and credit risk reports, Peruvian experience. International Journal of Business \& Management, 7(24), 35-43. doi: 10.5539/ijbm.v7n24p35

Cochrane, J. (2005). Asset pricing (Rev. ed.). New Jersey, USA: Princeton University Press.

Damasceno, D. L., Artes, R., \& Minardi, A. M. A. F. (2008). Determinação de rating de crédito de empresas brasileiras com a utilização de índices contábeis. Revista de Administração da Universidade de São Paulo, 43(4), 344-355.

Dichev, I. D., \& Piotroski, J. D. (2001). The long-run stock returns following bond ratings changes. Journal of Finance, 56(1), 173-203. doi: 10.1111/0022-1082.00322

Ederington, L. H., \& Goh, J. C. (1998). Bond rating agencies and stock analysts: who knows what when. Journal of Financial and Quantitative Analysis, 33(4), 569-585.

Ee, B. C. B. (2008). The impact of credit watch and bond rating changes on abnormal stock returns for Non-USA domiciled corporations (Master Thesis). Singapore Management University, Singapore. Retrieved from http://ink.library.smu.edu.sg/etd_coll/44

Elayan, F. A., Hsu, W. H, \& Meyer, T. O. (2003). The informational content of credit rating announcements for share prices in a small market. Journal of Economics and Finance, 27(3), 337-356. doi: 10.1007/BF02761570

Goh, J. C. Y., \& Ederington, L. H. (1999). Cross sectional variation of the effect of bond rating changes on stock prices. The Quarterly Review of Economics and Finance, 39(1), 101-112. doi: 10.1016/s1062-9769(99)80006-4

Griffin, P. A., \& Sanvicente, A. Z. (1982). Common stock returns and rating changes: a methodological comparison. The Journal of Finance, 37(1), 103-119. doi: 10.1111/j.15406261.1982.tb01098.x

Holthausen, R. W., \& Leftwich, R. W. (1986). The effect of bond rating changes on common stock prices. Journal of Financial Economics, 17(1), 57-89. doi: 10.1016/0304-405X(86)90006-1 
Jorion, P., \& Zhang, G. (2007). Information effects of bond rating changes: the role of the rating prior to the announcement. Journal of Fixed Income, 16(4), 45-59. doi: 10.3905/jfi.2007.683317

Kloeckner, G. O. (1995). Estudos de eventos: análise de um método. Revista Brasileira de Administração Contemporânea, 1(2), 261-270.

Linciano, N. (2004). The reaction of stock prices to rating changes. Quaderni di Finanza. English version $\mathrm{n}^{\mathrm{o}}$ 57. Commissione Nazionale Per La Società e La Borsa, Rome, Italy. Retrieved from http://www.google.com.br/url?sa=t\&rct=j\&q=\&esrc=s\&frm=1\&source=web\&cd=1\&ved=0CD EQFjAA\&url=http\%3A\%2F\%2Fwww.consob.it\%2Fdocumenti\%2Fquaderni\%2Fqdf57en.pdf\& ei=qasaUr37M8LW2AXm0IGQCA\&usg=AFQjCNElBEHPKy81Vtx4PeHJD2yDvam5dA\&bv $\mathrm{m}=$ bv. 51156542 ,d.eWU

Minardi, A. M. A. F. (2008). Probabilidade de inadimplência de empresas brasileiras refletida nas informações do mercado acionário. RAC Eletrônica, 2(2), 311-329. Retrieved from http://www.anpad.org.br/periodicos/arq_pdf/a_740.pdf

Minardi, A. M. A. F., Sanvicente, A. Z., \& Artes, R. (2007, August). A methodology for estimating credit ratings and the cost of debt for business units and privately-held companies. Proceedings of the Credit Scoring Conference, Edinburgh, UK, 10.

Moody's Investors Service. (2010). Special comment: Latin American corporate default and recovery rates 1990-H1 2010. Retrieved from http://www.alacrastore.com/research/moodys-global-creditresearch-Latin_American_Corporate_Default_and_Recovery_Rates_1990_H1_2010_excel_dataPBC_127420

Servigny, A., \& Renault, O. (2004). Measuring and managing credit risk. New York, USA: McGraw Hill.

Standard \& Poor's. (2009). Use of creditwatch and outlooks. Retrieved from http://82.80.247.35/\$sitepreview/maalot.co.il/credit\%20policy.pdf

Vassalou, M., \& Xing, Y. (2004). Default risk in equity returns. The Journal of Finance, 59(2), 831868. doi: $10.1111 / \mathrm{j} .1540-6261.2004 .00650 . x$

World Federation of Exchanges. (2010). Domestic market capitalization (in USD millions). Retrieved from http://www.world-exchanges.org/files/statistics/excel/Ts2\%20Market\%20cap..XLS 